\title{
Serum Zinc, Copper and Albumin in Paired Mothers and Their Term Newborn in a Tertiary Hospital in Nigeria
}

\author{
Ayodele Ojuawo*, Aishat Saka, Omotayo Adesiyun, Tope Obasa, Bunmi Olarinoye, \\ Kike Adesina, Abayomi Biliaminu, Adedeji Aderibigbe, Musibau AdulAzeez
}

Department of Paediatrics, Obstetrics \& Gynaecology, Chemical Pathology, Epidemiology \& Community Health, University of Ilorin Teaching Hospital, Ilorin, Nigeria

Email: *ayojuawo@yahoo.com

How to cite this paper: Ojuawo, A., Saka, A., Adesiyun, O., Obasa, T., Olarinoye, B., Adesina, K., Biliaminu, A., Aderibigbe, A. and AdulAzeez, M. (2018) Serum Zinc, Copper and Albumin in Paired Mothers and Their Term Newborn in a Tertiary Hospital in Nigeria. Open Journal of Pediatrics, 8, 273-282.

https://doi.org/10.4236/ojped.2018.83028

Received: August 20, 2018

Accepted: September 18, 2018

Published: September 21, 2018

Copyright (c) 2018 by authors and Scientific Research Publishing Inc. This work is licensed under the Creative Commons Attribution International License (CC BY 4.0).

http://creativecommons.org/licenses/by/4.0/

\begin{abstract}
Objective: This study assessed the serum zinc, copper and albumin levels in paired mother and newborns in the immediate neonatal period to establish the relationship between the pair, and the influence of maternal micronutrient status on that of the newborn if any. Methods: The sociodemographic characteristics of the mothers were obtained using a structured questioner after informed consent was obtained from the parents of the baby. At delivery, paired mother and newborns had their serum zinc, copper and albumin assayed, using cord blood in the newborn. Result: One hundred and thirty five mothers and their paired term newborns completed the study. The mean age of the mothers was $29.2 \pm 4.6$ years with $67 \%$ within the age bracket 20 to 30 years. Seventy three percent of the mothers attained tertiary education and $22 \%$ had secondary education. The mean serum zinc was significantly higher in the newborn $(3.67 \pm 1.49 \mu \mathrm{mol} / \mathrm{L})$ than in the mothers $(2.20 \pm 1.01$ $\mu \mathrm{mol} / \mathrm{L}), \mathrm{p}=0.0001$, with a feto-maternal ratio of 1.6 to 1 . Copper was significantly higher in the mothers $(4.27 \pm 1.77 \mu \mathrm{mol} / \mathrm{L})$, than in the newborns $(2.84 \pm 0.92 \mu \mathrm{mol} / \mathrm{L})(\mathrm{p}=0.001)$, with a maternal-fetal ratio of 1.5 to 1 . Mean serum albumin was significantly lower in the newborns than in the mothers ( $p>0.011$ ). Conclusion: This study established that term newborns have higher serum zinc, a lower serum copper and albumin levels than their maternal levels. The distribution of these trace elements is probably protective in the newborns against infection.
\end{abstract}

\section{Keywords}

Maternal-Newborn Pair, Zinc, Copper, Albumin 


\section{Introduction}

Pregnancy is associated with increased nutritional needs due to the physiologic changes of the woman and the metabolic demands of the embryo/fetus. Proper maternal nutrition during pregnancy is thus imperative for the health of both the woman and the offspring [1]. The nutritional requirements in pregnancy include calories, protein, lipids and micronutrients. Micronutrients are elements and vitamins required in trace amounts for normal growth and development which influence the health of both the mother and foetus [2] [3] [4].

Multiple micronutrient deficiencies can result from poor quality diet, inadequate animal protein intake especially in developing countries [5].

During pregnancy, micronutrients deficiencies are particularly common due to increased nutrient requirements of the mother and the developing fetus.

Zinc is an important micronutrient essential for normal growth and development of the foetus and it plays a critical role in many cellular reactions including gene transcription, cell division and differentiation. It has also been found to be a cause of growth retardation in both term and ex-preterm infants. Its deficiency has been associated with neural tube defects [6] [7].

Copper is a cofactor in several metalloproteins, essential for oxidative metabolism, myelination and the metabolism of several steroid hormones. Clinical copper deficiency is a recognised hazard among preterm infants. Various investigators have studied micronutrients in newborn babies and within the first year of life because of their importance in growth and development [6] [7] [8] [9] [10]. Review of literature on micronutrients in mothers and neonates appears as though values differ with race, geographical location, environmental dietary and nutritional factors among others. Thus, use of reference values cannot be generalised for all population types [11] [12].

Albumin is the carrier protein for the micronutrients, hence, its level influences micronutrient levels to an extent that micronutrient levels cannot be interpreted correctly without concomitant serum albumin levels.

The relationship between the mother and the neonate in terms of the sharing of nutrients in this environment is still not totally understood nor well studied. Even though several studies have been done on maternal and infant levels of micronutrients [13] [14] [15], most of these studies were not done on paired maternal and fetal sera most studies done in this environment on micronutrients in mothers were not paired with their newborns, neither were the studies in the neonates paired with their mothers. Thus the relationship between the mother and their newborn in this environment is not established, hence the need for this study to see the relationship between the two individuals.

\section{Methods}

This is a prospective cross sectional study carried out over a one year period (July 2015 to June 2016) where mothers with term pregnancy at the onset of labor and their respective newborn babies that were delivered in the labour room 
of the University of Ilorin Teaching Hospital (UITH) were studied.

Ethical approval for this study was obtained from University of Ilorin Teaching Hospital Ethical Research Committee (registered with National Health Research Ethics: NHREC/02/05/2010).

Informed consent was obtained from both the father and the mother of the newborns during the antenatal period/before delivery.

The subjects were consecutive women presenting in labor and had completed labor at participation, at the labor ward of the hospital as well as their newborns when successfully delivered.

All consecutive admissions into the labor ward that fulfilled the inclusion criteria were enrolled into the study until the calculated minimum sample size of 120 mother and newborn pair is achieved. All the women recruited were assessed to be in good health and had experienced no medical complications during pregnancy.

Mothers who received steroids (known to influence the level of many nutrients), micronutrient supplementation (except routine drugs), chronic diseases, and babies born with major congenital abnormalities were excluded from the study.

Five milliliters of blood was drawn under aseptic condition from the mother and five millilitres of cord blood was obtained for assay. The serum was separated immediately and sent to the laboratory and stored at $-80^{\circ} \mathrm{C}$ until assayed.

Serum zinc was assayed with Randox kit (Cat. No. ZN 2341; Randox Labs Ltd., Crumlin, UK) according to the instructions of the manufacturer [16].

Serum copper was measured spectrophotometrically with RANDOX kit (Cat. No. ZN 2341; Randox Labs Ltd., Crumlin, UK) according to instructions introduced by manufacturer [17].

Serum total protein and albumin were analyzed using the biuret [18] and bromocresol green methods [19], respectively. Albumin was assayed using kits from Agappe Diagnostics, Kerala, India.

Data analysis-SPSS statistical software package version 16 was used for data analysis. The variables were analysed using a non-parametric test method, the two-sample Wilcoxon rank-sum Mann-Whitney test. Continuous variables were compared using paired student t-test. Pearson's correlation coefficient was also used to correlate categorical variables and $\mathrm{p}$ value was set at less than 0.05 .

\section{Result}

One hundred and thirty five mother/newborn pair completed the assessment process and were analysed.

Table 1 shows that the mean age of the mothers was $29.2 \pm 4.6$ years with $67.4 \%$ within the age bracket 20 to 30 years. All the mothers attained some level of education with $74.1 \%$ attaining tertiary education and $22.9 \%$ with secondary education. Eighty one percent of the mothers had some form of employment whilst $18.5 \%$ were unemployed. 
Table 1. The socio-demographic characteristics of the mothers studied.

\begin{tabular}{|c|c|c|}
\hline Variables & $\mathrm{n}=135$ & Freq (\%) \\
\hline \multicolumn{3}{|l|}{ Age in years } \\
\hline$\leq 20$ & & $2(0.7)$ \\
\hline $21-30$ & & $90(67.4)$ \\
\hline$\geq 31$ & & $43(31.8)$ \\
\hline Mean Age & $29.2 \pm 4.6$ & \\
\hline \multicolumn{3}{|c|}{ Educational Status } \\
\hline Primary & & $4(2.9)$ \\
\hline Secondary & & $31(22.9)$ \\
\hline Tertiary & & $100(74.1)$ \\
\hline \multicolumn{3}{|l|}{ Tribe } \\
\hline Yoruba & & $119(88.1)$ \\
\hline Hausa & & $3(2.2)$ \\
\hline Ibo & & $10(7.5)$ \\
\hline Others & & $3(2.5)$ \\
\hline \multicolumn{3}{|l|}{ Religion } \\
\hline Christianity & & $40(29.6)$ \\
\hline Islam & & $91(67.4)$ \\
\hline Others & & $4(2.9)$ \\
\hline \multicolumn{3}{|l|}{ Occupation } \\
\hline Unemployed & & $25(24.5)$ \\
\hline Self Employed & & $51(37.8)$ \\
\hline Employed & & $59(43.7)$ \\
\hline \multicolumn{3}{|c|}{ Place of Ante Natal Care } \\
\hline UITH & & $108(80.0)$ \\
\hline Outside UITH & & $27(20.0)$ \\
\hline \multicolumn{3}{|l|}{ Booking Status } \\
\hline Booked & & $113(83.7)$ \\
\hline Unbooked & & $22(16.3)$ \\
\hline \multicolumn{3}{|l|}{ Cigarette Use } \\
\hline Yes & & $0(0)$ \\
\hline No & & $135(100)$ \\
\hline \multicolumn{3}{|l|}{ Alcohol Use } \\
\hline Yes & & $0(0)$ \\
\hline No & & $135(100)$ \\
\hline
\end{tabular}

Ninety five percent of the mothers received antenatal care $(80 \%$ within UITH). None of the mothers drink alcohol or smoke. All the mothers that provided the information took haematinics/multivitamins.

Ninety two percent of the babies were Appropriate for Gestational Age, whilst 5.1\% were Large for Gestational Age, with the babies having a mean birth weight of $3.6 \pm 1.2 \mathrm{~kg}$, mean length of $49.1 \pm 3.3 \mathrm{~cm}$, and a mean head circumference of $34.2 \pm 4.3 \mathrm{~cm}$ (Table 2).

The mean serum zinc was significantly higher in the newborn $(3.67 \pm 1.49$ $\mu \mathrm{mol} / \mathrm{L})$ than in the mothers $(2.20 \pm 1.01 \mu \mathrm{mol} / \mathrm{L}), \mathrm{p}=0.0001$, with Figure 1 
Table 2. Maternal and newborn anthropometric parameters of the total study population.

(a)

\begin{tabular}{cc}
\hline Variables & \\
\hline Maternal & Mean \pm SD \\
Mean Maternal Height $(\mathrm{cm})$ & $159.8 \pm 19.7$ \\
Mean Booking Weight $(\mathrm{kg})$ & $73.5 \pm 18.5$ \\
Mean Last Weight at ANC Visit (kg) & $78.8 \pm 17.4$ \\
Mean Weight at Presentation in Labour Ward & $82.3 \pm 20.5$ \\
BMI (kgm $\left.{ }^{2}\right)$ & $29.9 \pm 11.3$ \\
& Median (IQR) \\
& $24.5(17.8)$ \\
Duration of Pregnancy at Booking (wks) & $39.0(2.0)$ \\
\hline
\end{tabular}

(b)

\begin{tabular}{cc}
\hline Newborn & \\
\hline Growth Classification & Freq (\%) \\
SGA & $3(2.2)$ \\
AGA & $125(92.5)$ \\
LGA & $7(5.1)$ \\
Anthropometry & Mean \pm SD \\
Mean Birth Weight $(\mathrm{kg})$ & $3.6 \pm 4.2$ \\
Mean Length $(\mathrm{cm})$ & $49.1 \pm 3.3$ \\
Mean Head Circumference $(\mathrm{cm})$ & $34.2 \pm 4.3$ \\
\hline
\end{tabular}

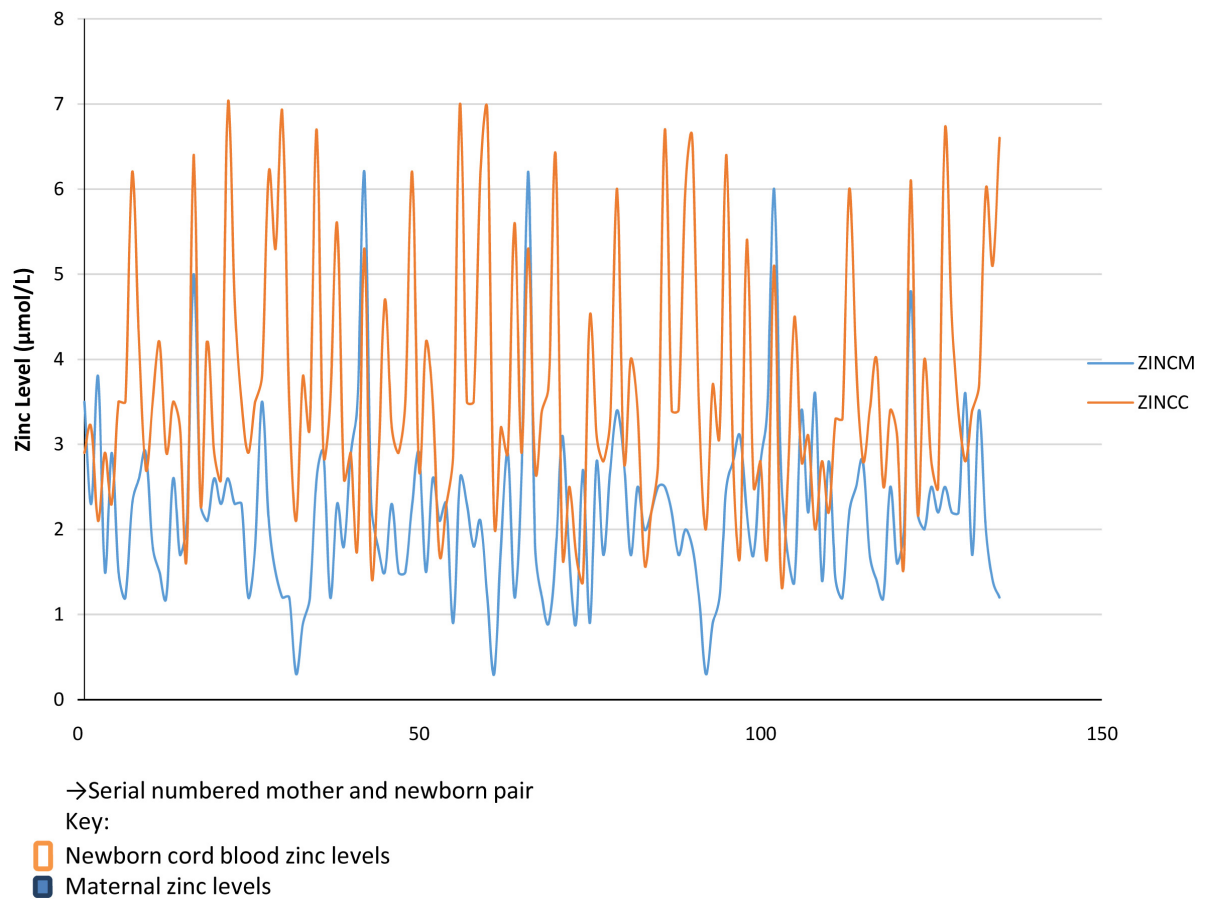

Figure 1. Zinc levels in paired mother and their term newborns.

showing that newborns have a higher serum zinc levels that their paired mothers at a ratio of 1.6 to 1 . 
Copper was significantly higher in the mothers $(4.27 \pm 1.77 \mu \mathrm{mol} / \mathrm{L})$, than in the newborn $(2.84 \pm 0.92 \mu \mathrm{mol} / \mathrm{L})(\mathrm{p}=0.001)$, with Figure 2 showing that serum copper levels were higher in the mothers than their paired newborns at a ratio of 1.5 to 1 (Table 3 ).

There is a positive correlation between maternal serum copper and cord blood copper levels in this study as a high value in mothers reflect in the newborn levels.

The serum total protein and albumin levels were significantly higher in the mothers than in the newborns $(\mathrm{p}=0.001)$, however albumin levels are comparable at a ratio of 1.07 to 1 in the mother and newborn.

Table 4 shows that there is a positive correlation between the mothers and their newborns for total protein and albumin levels $(\mathrm{p}=0.001)$, but no significant correlation for zinc and copper $(\mathrm{p}=0.27)$.

\section{Discussion}

This study shows a significantly higher zinc levels in paired term newborns than their mothers in this environment, a finding that establishes the relationship between the mother and their paired newborns in this locality. This finding is similar to that of Rupal et al. in India [20], and other workers [21] [22], who reported a higher serum zinc in the cord blood than in the serum of the mothers in a ratio ranging from 1.8 to 1 and 1.3 to 1 . The ratio in the current study is 1.6 to 1 , newborn to mother. Zinc is an important micronutrient essential for normal growth and development of the foetus and it plays a critical role in many cellular

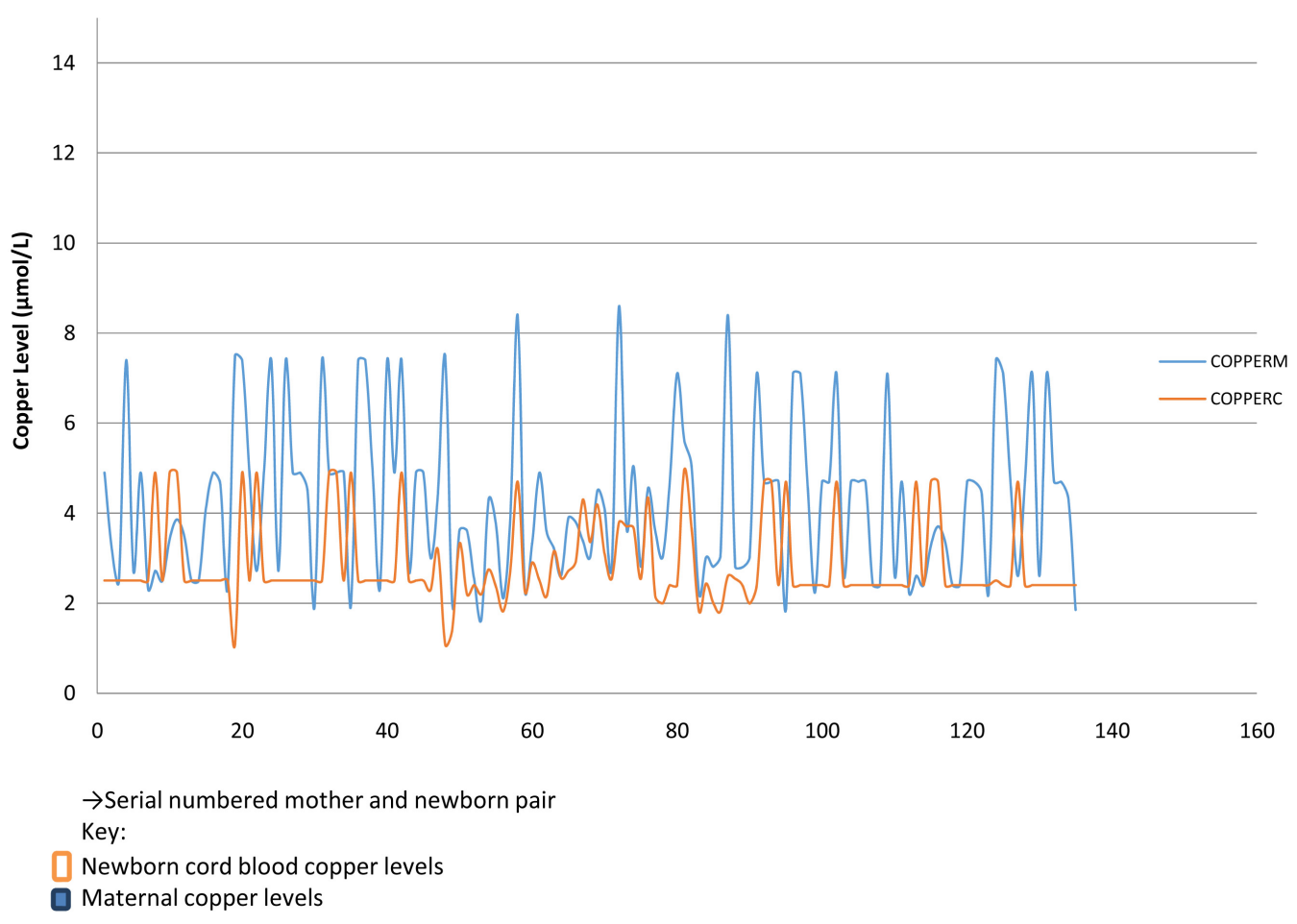

Figure 2. Copper levels in paired mother and their term newborns. 
Table 3. The mean serum zinc, copper, total protein and albumin levels in paired mother and their term newborn.

\begin{tabular}{|c|c|c|c|c|}
\hline Variable & $\mathbf{n}$ & Mean \pm SD & $t$ test & $\mathrm{p}$ value \\
\hline \multicolumn{5}{|c|}{$\operatorname{Zinc}(\mu \mathrm{mol} / \mathrm{L})$} \\
\hline $\begin{array}{c}\text { Mother } \\
\text { Baby }\end{array}$ & $\begin{array}{l}135 \\
135\end{array}$ & $\begin{array}{l}2.20 \pm 1.01 \\
3.67 \pm 1.49\end{array}$ & -9.49 & 0.0001 \\
\hline \multicolumn{5}{|c|}{ Copper $(\mu \mathrm{mol} / \mathrm{L})$} \\
\hline $\begin{array}{l}\text { Mother } \\
\text { Baby }\end{array}$ & & $\begin{array}{l}4.24 \pm 1.77 \\
2.84 \pm 0.92\end{array}$ & 8.50 & 0.001 \\
\hline \multicolumn{5}{|c|}{ Total Protein $(\mathrm{gm} / \mathrm{L})$} \\
\hline $\begin{array}{l}\text { Mother } \\
\text { Baby }\end{array}$ & & $\begin{array}{l}70.87 \pm 18.87 \\
53.74 \pm 12.29\end{array}$ & 8.75 & 0.001 \\
\hline \multicolumn{5}{|c|}{ Albumin $(\mathrm{gm} / \mathrm{L})$} \\
\hline $\begin{array}{l}\text { Mother } \\
\text { Baby }\end{array}$ & & $\begin{array}{l}44.35 \pm 7.61 \\
41.35 \pm 7.21\end{array}$ & 3.30 & 0.01 \\
\hline
\end{tabular}

Maternal: Newborn ratio, @ Zinc 1:1.6; @ Copper 1.5:1; @ Albumin 1.07:1; @ Total Protein 1.3:1.

Table 4. Correlation between mother and their term newborn for serum zinc, copper, albumin and total protein.

\begin{tabular}{cccc}
\hline Variable & $\mathbf{n}$ & Pearson Correlation Coefficient " $\mathbf{~}$ " & p value \\
\hline Zinc & & & \\
Mother & 135 & 0.096 & 0.27 \\
Newborn & 135 & & \\
Copper & & & \\
Mother & 135 & 0.049 & 0.57 \\
Newborn & 135 & & \\
Albumin & & & \\
Mother & 135 & 0.33 & \\
Newborn & 133 & & 0.001 \\
Total Protein & & & \\
Mother & 135 & 0.32 & \\
Newborn & 135 & & \\
\end{tabular}

reactions including gene transcription, cell division and differentiation. Its deficiency has also been found to be a cause of growth retardation in both term and ex-preterm infants [6] [7].

The albumin levels are within normal limits in both the mothers and their paired newborns, hence, the distribution of zinc in the two groups is a true reflection of the zinc status of the subjects. This finding suggests that zinc is distributed in favour of the newborn. Zinc is transported across the placenta during the last trimester of pregnancy at the rate of $3.82 \mathrm{micromol} / \mathrm{L} / \mathrm{kg} /$ day [23]. Zinc protects the cell membrane against oxidative and immunologic damage, and is important in protein metabolism and synthesis [24]. Zinc is also important in immune cellular response in man as it decreases natural killer cell activity [25] 
[26], hence, its higher level in the newborn is probably protective.

Serum copper levels were significantly higher in the mothers two-folds than in their paired newborn in this study. This finding is in consonance with the report from previous studies in Europe and Asia, where the serum copper levels in the mothers were significantly higher than the levels in the newborns up to four folds in some of the studies [27] [28] [29]. Also there is a positive correlation between maternal serum copper and cord blood copper levels in this study, a finding that is similar to the findings in some other reports [29].

Copper is required for fighting infection and are therefore increased in serum in response to infection. The sharp gradient from the mother to the baby is probably as a result of placental activity which protects the newborn from high serum copper levels. The higher copper levels in the mother might also be as a result of the high molecular weight, and the transport protein in the blood stream which makes it more difficult to transport across the placenta [30].

Clinical copper deficiency is a recognised hazard among preterm infants [6], but the term infants in this study did not show a deficiency of copper, rather a steep gradient of serum copper levels from mother to the newborn.

The mothers and their newborns have a mean albumin levels that is within the normal range which is a reflection of the nutritional state of the mothers and the term babies.

\section{Conclusions}

We conclude that there is an established relationship between newborns and their paired mothers in terms of the serum levels of some trace elements at birth. Term babies have a higher serum zinc levels, and a lower serum copper levels than their paired mothers. Newborn zinc levels are 1.5 times that of their mothers whilst serum copper levels are lower two folds than in their mothers, with the placental playing a role in preventing high copper levels in the newborn.

The high copper level in the mothers is probably a reflection of infections in the mother, whilst the baby is protected by the higher zinc levels.

\section{Limitation of the Study}

This study is limited in its scope, as a larger number of paired mother and newborns, and more micronutrients such as selenium could have been studied but due to lack of fund and some logistics (the study is non-grant funded).

\section{Conflicts of Interest}

The authors declare that they have no competing interests.

\section{References}

[1] Abu-Saad, K. and Fraser, D. (2010) Maternal Nutrition and Birth Outcome. Epidemiologic Reviews, 32, 5-25. https://doi.org/10.1093/epirev/mxq001

[2] Haider, B.A. and Bhutta, Z.A. (2006) Multiple-Micronutrient Supplementation for 
Women during Pregnancy. Cochrane Database of Systematic Reviews, 4, 4-18.

[3] Shah, P.S. and Ohlsson, A. (2009) Knowledge Synthesis Group on Determinants of Low Birth Weight and Preterm Births. Effects of Prenatal MMN Supplementation on Pregnancy Outcomes: A Meta-Analysis. CMAJ, 180, E99-E108.

[4] Ronsmans, C., Fisher, D.J., Osmond, C., Margetts, B.M. and Fall, C.H. (2009) Maternal Micronutrient Supplementation Study Group: Multiple Micronutrient Supplementation during Pregnancy in Low-Income Countries: A Meta-Analysis of Effects on Stillbirths and on Early and Late Neonatal Mortality. Food and Nutrition Bulletin, 30, S547-S557. https://doi.org/10.1177/15648265090304S409

[5] Fall, C.H., Fisher, D.J., Osmond, C. and Margetts, B.M. (2009) Maternal Micronutrient Supplementation Study Group: Multiple Micronutrient Supplementation during Pregnancy in Low-Income Countries: A Meta-Analysis of Effects on Birth Size and Length of Gestation. Food and Nutrition Bulletin, 30, S533-S546. https://doi.org/10.1177/15648265090304S408

[6] Osungbade, K.O. and Oladunjoye, A.O. (2012) Preventive Treatments of Iron Deficiency Anaemia in Pregnancy: A Review of Their Effectiveness and Implications for Health System Strengthening. Journal of Pregnancy, 2012, Article ID: 454601. https://doi.org/10.1155/2012/454601

[7] Lumley, J., Watson, M. and Bower, C. (2000) Periconceptual Supplementation with Folate and/or Multivitamins for Preventing Neural Tube Defects (Cochrane Review). The Cochrane Library Update Software, Oxford.

[8] Bailey, L.B., Mahan, C.S. and Dimperio, D. (1980) Folacin and Iron Status in Low-Income Pregnant Adolescents and Mature Women. The American Journal of Clinical Nutrition, 33, 1997-2001. https://doi.org/10.1093/ajcn/33.9.1997

[9] Scholl, T.O. and Johnson, W.G. (2000) Folic Acid: Influence on the Outcome of Pregnancy. The American Journal of Clinical Nutrition, 7, 1295-1303. https://doi.org/10.1093/ajcn/71.5.1295s

[10] Kim, M.W., Hong, S.C., Choi, J.S., Han, J.Y., Oh, M.J., Kim, H.J., Nava-Ocampo, A. and Koren, G. (2012) Homocysteine, Folate and Pregnancy Outcomes. Journal of Obstetrics and Gynaecology, 32, 520-524. https://doi.org/10.3109/01443615.2012.693984

[11] Spatling, L. and Spatling, G. (1988) Magnesium Supplementation in Pregnancy: A Double Blind Study. British Journal of Obstetrics and Gynaecology, 95, 120-125.

[12] Ladipo, O. (2000) Nutrition in Pregnancy: Mineral and Vitamin Supplements. American Journal of Clinical Nutrition, 72, 280S-290S. https://doi.org/10.1093/ajcn/72.1.280S

[13] Tabrizi, F.M. and Pakdel, F.G. (2014) Serum Level of Some Minerals during Three Trimesters of Pregnancy in Iranian Women and Their Newborns: A Longitudinal Study. Indian Journal of Clinical Biochemistry, 29, 174-180. https://doi.org/10.1007/s12291-013-0336-x

[14] Cockburn, F., Belton, N.R., Purvis, R.J., et al. (1980) Maternal Vitamin D Intake and Mineral Metabolism in Mothers and Their Newborn Infants. British Medical Journal, 281, 11-14. https://doi.org/10.1136/bmj.281.6232.11

[15] Darnton-Hill, I. and Mkparu, U.C. (2015) Micronutrients in Pregnancy in Low-and-Middle-Income-Countries. Nutrients, 7, 1744-1768. https://doi.org/10.3390/nu7031744

[16] Johnsen, Ø. and Eliasson, R. (1987) Evaluation of a Commercially Available Kit for the Colorimetric Determination of Zinc. International Journal of Andrology, 10, 435-440. https://doi.org/10.1111/j.1365-2605.1987.tb00216.x 
[17] Abe, A., Yamashita, S. and Noma, A. (1989) Sensitive Direct Colorimetric Assay for Copper in Serum. Clinical Chemistry, 35, 552-554.

[18] Tietz, N.W. (1986) From Proteins. In: Textbook of Clinical Chemistry, W.B. Saunders Co., Philadelphia, 588.

[19] Layne, E. (1957) Spectrophotometric and Turbidimetric Methods for Measuring Proteins. Methods in Enzymology, 10, 447-455. https://doi.org/10.1016/S0076-6879(57)03413-8

[20] Jeswani, R.M. and Vani, S.N. (1991) A Study of Serum Zinc Levels in Cord Blood of Neonates and Their Mothers. The Indian Journal of Pediatrics, 58, 683-687. https://doi.org/10.1007/BF02820191

[21] Kurz, D.L., Eyring, E.J. and Roach, J.E. (1973) Serum Zinc in Newborn. Biol Neonatology, 23, 180-183. https://doi.org/10.1159/000240599

[22] Shaw, J.C.L. (1979) Trace Elements in the Fetus and Young Infants. The American Journal of Diseases of Children, 133, 1260-1280. https://doi.org/10.1001/archpedi.1979.02130120052011

[23] Berfenstam, R. (1952) Studies on Blood Zinc: Clinical and Experimental Investigation into Zinc Content of Plasma and Blood Corpuscles with Special Reference to Infancy. Acta Paediatrica, 41, 389-391.

[24] Cacey, C. (1979) Human Zinc Deficiency. Postgrad Doctor, 106-116.

[25] Nwagha, U.I., Ogbodo, S.O., Nwogu-Ikojo, E.E., et al. (2011) Copper and Selenium Status of Healthy Pregnant Women in Enugu, Southeastern Nigeria. Nigerian Journal of Clinical Practice, 14, 408-412. https://doi.org/10.4103/1119-3077.91745

[26] Airede, A.I. (1997) Zinc Levels in Nigerian Full Term Newborns from Birth Till 6 Months. East African Medical Journal, 74, 221-223.

[27] Prasad, A.S. (1976) Deficiency of Zinc in Man and Its Toxicity: In Trace Elements in Human Health and Disease. 1st Edition, Academic Press, New York and London.

[28] Igbal, A.S., Shahidullahi, M., Islam, M.N., Akfers, S. and Banu, S. (2001) Serum Zinc and Copper Levels in the Maternal Blood and Cord Blood of Neonates. The Indian Journal of Pediatrics, 68, 523-526. https://doi.org/10.1007/BF02723246

[29] Algemie, M.H. and Khatri, P.C. (1998) Serum Copper in Newborns and Their Mothers. The Indian Journal of Pediatrics, 65, 899-903. https://doi.org/10.1007/BF02831358

[30] Schulpiskit, K.H., Karakonstantakis, T., Gayrili, S., Chronopoulou, G., Karikas, A., Vlachos, G. and Papassotirion, I. (2004) Maternal-Neonatal Serum Selenium and Copper Levels in Greeks and Albanians. European Journal of Clinical Nutrition, 58, 1314-1318. https://doi.org/10.1038/sj.ejcn.1601967 